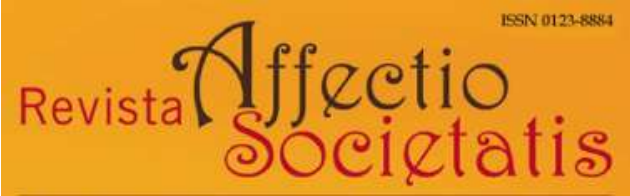

Departamento de Psicoanálisis / Universidad de Antioquia

Revista Affectio Societatis

Departamento de Psicoanálisis

Universidad de Antioquia

revistaaffectiosocietatis@udea.edu.co

ISSN (versión electrónica): 0123-8884

Colombia

2020

André Fernando Gil Alcon Cabral

O anormal e o patológico de Foucault a Freud: o discurso jurídico-psiquiátrico e a psicanálise

Revista Affectio Societatis, Vol. 17, N. ${ }^{\circ} 33$, julio-diciembre de 2020

Art. \# 9 (pp. 214-244)

Departamento de Psicoanálisis, Universidad de Antioquia

Medellín, Colombia 


\title{
O ANORMAL E O PATOLÓGICO DE FOUCAULT A FREUD: O DISCURSO JURÍDICO-PSIQUIÁTRICO E A PSICANÁLISE
}

\author{
André Fernando Gil Alcon Cabral ${ }^{1}$ \\ Universidad Federal de Minas Gerais, Brasil \\ cabral.afga@gmail.com \\ https://orcid.org/0000-0002-1567-621X
}

DOI: 10.17533/udea.affs.v17n33a09

Resumo

Na década de 70, Michel Foucault empregou severas críticas à psicanálise. Para o autor, ela se constituiu como um saber normativo capaz de responder à demanda médico-jurídica. Desse modo, o saber sobre as pulsões sexuais foi fundamental para construir a psicopatologia moderna. Daí as figuras da criança masturbadora e da criança perverso polimorfa surgirem como genealogia do monstro sexual ou anormal. Foucault então interpreta que a psicanálise surge na medida em que diagnostica o sujeito segundo os diferentes destinos frente ao complexo de Édipo. Neste trabalho, verificaremos como a psicanálise freudiana se habilita responder às críticas de Foucault. A nosso ver, o conceito de pulsão de morte será fundamental para essa empreitada.

Palavras chave: Psiquiatria; Psicanálise; Direito; Anormal; Patológico.

\section{LO ANORMAL Y PATOLÓGICO DE FOUCAULT A FREUD: EL DISCURSO JURÍDICO-PSIQUIÁTRICO Y EL PSICOANÁLISIS}

\section{Resumen}

En la década de 1970, Michel Foucault hizo fuertes críticas al psicoanálisis. Para el autor, se constituyó como un saber normativo capaz de responder a la demanda médico-jurídica. De esta manera, el conocimiento

1 Psicanalista, doutorando em Psicologia pela UFMG, mestre em Psicologia e especialista em Filosofia pela UFMG. Graduou-se em Psicologia pelo Centro Universitário Newton Paiva. 
sobre las pulsiones sexuales fue fundamental para construir la psicopatología moderna. Por lo tanto, las figuras del niño masturbador y del niño polimórfico perverso aparecen como la genealogía del monstruo sexual o anormal. Foucault interpreta entonces que el psicoanálisis surge en la medida en que diagnostica al sujeto según los diferentes destinos frente al complejo de Edipo. En este trabajo comprobaremos cómo el psicoanálisis freudiano es capaz de responder a las críticas de Foucault. En nuestra opinión, el concepto de pulsión de muerte será fundamental para este propósito.

Palabras llave: Psiquiatría; Psicoanálisis; Derecho; Anormal; Patológico.

\section{THE ABNORMAL AND PATHOLOGICAL FROM FOUCAULT TO FREUD: THE LEGAL-PSYCHIATRIC DISCOURSE AND PSYCHOANALYSIS}

\section{Abstract}

In the 1970s, Michel Foucault made strong criticisms of psychoanalysis. To the author, it was constituted as a normative knowledge capable of responding to the medical-legal demand. In this way, the knowledge about sexual drives was fundamental to build modern psychopathology. Therefore, the figures of the masturbating child and the polymorphous perverse child appear as the genealogy of the sexual or abnormal monster. Foucault then interprets that psychoanalysis arises insofar as it diagnoses the subject according to the different destinies regarding the Oedipus complex. In this paper, we verify how Freudian psychoanalysis can respond to Foucault's criticisms. In our opinion, the concept of death drive will be fundamental for this purpose.

Keywords: psychiatry, psychoanalysis, law, abnormal, pathology. 


\section{L'ANORMAL ET LE PATHOLOGIQUE DE FOUCAULT À FREUD : LE DISCOURS JURIDICO-PSYCHIATRIQUE ET LA PSYCHANALYSE}

\section{Résumé}

Dans les années 1970, Michel Foucault a fait de fortes critiques de la psychanalyse. Pour l'auteur, elle a été constituée comme un savoir normatif capable de répondre à la demande médico-légale. Ainsi, la connaissance des pulsions sexuelles a été fondamentale pour construire la psychopathologie moderne. Par conséquent, les figures de l'enfant masturbant et de l'enfant polymorphe pervers surgissent comme la généalogie du monstre sexuel ou anormal. Foucault explique alors que la psychanalyse naît dans la mesure où elle diagnostique le sujet en fonction des différents destins face au complexe d'Oedipe. Dans cet article, nous verrons comment la psychanalyse freudienne est capable de répondre aux critiques de Foucault. Le concept de pulsion de mort sera fondamental dans ce dessein.

Mots-clés : psychiatrie ; psychanalyse ; droit ; anormal ; pathologique 


\section{Introdução}

A psiquiatria moderna e a psicanálise contribuíram mutuamente para a formação de seus saberes. A psiquiatria permitiu fundar e/ ou precipitar a classificação nosológica para a psicanálise, ao mesmo tempo em que essa última possibilitou à psiquiatria fundamentar e compreender a etiologia das doenças psíquicas e somáticas. Encontramos aí uma imbricação fundamental e determinante entre essas práticas.

Inicialmente, podemos supor que se tratam de epistemologias que buscam formular e intervir sobre a patologia independentemente de qualquer relação com a dimensão de poder. Afinal, o saber psicopatológico aparentemente busca decifrar a verdade imposta pelos sinais e pela semiologia da doença. Curando os sintomas ou aliviando o sofrimento, ambas as práticas buscam pinçar o enfermo, produzindo um corte preciso sobre o agente patogênico.

Para Michel Foucault (2010/1975), entretanto, não se constata tamanha neutralidade dessas práticas de tratamento, pois, psicanálise e psiquiatria se incluem no discurso de poder principalmente na medida em que respondem ao discurso jurídico. É pelo discurso jurídico ou, mais precisamente, pelo discurso judiciário, nessa espécie de tríade epistemológica, que veremos Foucault formalizar uma verdade médico-jurídica para a psicopatologia moderna.

Nesse sentido, a psiquiatria e a psicanálise se apresentam sobretudo como formas de conhecimento a responder às demandas do sistema judiciário no final do século XVIII, início do século XIX. Ora, mas em que medida o sistema judiciário interroga a ciência psiquiátrica e a psicanálise? Como o saber psiquiátrico-psicanalítico permitiu responder aos impasses jurídicos, formalizando assim uma verdade jurídico-científica? Essas são questões fundamentais para que consigamos localizar essas práticas clínicas na atualidade.

Comecemos por demonstrar a relação entre o sistema jurídico e a psiquiatria. 


\section{O monstro sexual como lacuna jurídico-médica}

No livro Os anormais, Foucault (2010/1975) nos apresenta a genealogia do anormal. Para tal, inicia pela figura do monstro, mas não qualquer monstro. Começa dizendo que a infração jurídica da lei natural não basta para constituir o monstro que lhe interessa. Temos aí a categoria da deformidade, da enfermidade, do defeito, mas esses não correspondem propriamente à figura do monstro, segundo sua apresentação no século XIX. Ora, mas em que consiste a diferença? Em outras palavras, qual o monstro que constitui o valor paradigmático para pensar a genealogia do anormal para Michel Foucault?

Foucault retomará três casos que serviriam de paradigma para a psiquiatria criminal. Veremos sobretudo a presença do que o autor nomeia como três casos de monstruosidade. Primeiramente, Foucault introduz o caso do monstro antropófago. Selestat é a mulher que mata a filha, corta-a em pedaços, e, logo depois, a cozinha com repolho para depois devorá-la. Selestat foi considerada juridicamente capaz de se responsabilizar pelo crime, isso é, "a mulher não era louca, porque, se matou a filha e comeu, o fez levada por um móvel que era admissível por todo o mundo: a fome" (Foucault, 2010/1975, pág. 95). Foucault ressalta que em 1817 reinava a fome na Alsácia. Com isso, o tribunal não considerou que haveria a presença de uma demência ou delírio, sendo ela considerada responsável juridicamente. "O caso foi esvaziado do ponto de vista psiquiátrico" (pág. 95).

Para o segundo caso, veremos ocorrer exatamente o oposto do caso de Selestat. O caso de Papavoine foi, por outro lado, "esvaziado como problema jurídico-psiquiátrico" (pág. 95) na medida em que o homem foi considerado incapaz de se responsabilizar juridicamente. $\mathrm{O}$ homem teria assassinado duas crianças que ele não conhecia. Questionado sobre as razões para tal ato, o réu descreveu que imaginou reconhecer nelas dois filhos da família real, os filhos da duquesa de Berry. "E, em torno disso, desenvolveu um certo número de temas, de crenças, de afirmações, que logo puderam ser postas, inscritas no registro do delírio, da ilusão, da falsa crença, logo da loucura" (pág. 95). 
Até, aqui, temos dois casos de monstruosidade. Porém, Foucault vai observar que o monstro que lhe interessa é sobretudo aquele que interroga o sistema judiciário exatamente na medida em que escapa tanto ao conceito de demência/loucura quanto à razão/responsabilidade penal. É o monstro que se apresenta entre a inimputabilidade e a imputabilidade. $\mathrm{O}$ autor se interessa especificamente pelo monstro que não se pode classificar no sistema jurídico e psiquiátrico, exigindo que se crie um saber sobre ele. Por isso, Foucault retomou a figura do monstro a partir do caso de Henriette Cornier.

Os relatos mencionam que, certo dia, Henriette apareceu na casa da vizinha e se ofereceu para tomar conta da filhinha desta, de dezoito meses. A vizinha, que havia hesitado num primeiro momento, permitiu que filha ficasse aos cuidados de Cornier. No instante seguinte, Henriette levou a menina para o quarto, e ali, com um facão, que havia trazido de antemão, cortou o pescoço da criança, separando a cabeça e o restante do corpo. Diante do corpo da menina, permaneceu por uns quinze minutos. Quando a vizinha veio buscar a criança, Cornier disse que a filha estava morta. A mulher sem acreditar duvidou, momento em que Henriette pegou a cabeça da garota, pôs em um avental, e a jogou pela janela. Quando indagada pela razão do ato: "Por quê? Ela responde: Foi uma ideia. E não foi possível tirar praticamente mais nada dela" (Foucault, 2010/1975, pág. 96).

Foucault observa que não vemos aí a identificação de um delírio, tampouco é possível descrever a razão do ato para que a mesma agisse conforme descrito. Para Foucault, na medida em que encontramos um crime sem razão, mas cometido por indivíduo dotado de razão, tornou-se impossível atestar ou atribuir qualquer saber jurídico-psiquiátrico. Isso porque nos vimos frente a uma lacuna de saber. No lugar dessa lacuna aberta entre a dicotomia da razão e da loucura, Foucault localiza Henriette.

Assim, "só há monstruosidade onde a desordem da lei natural vem tocar, abalar, inquietar o direito, seja o direito civil, o direito canônico ou o direito religioso" (Foucault, 2010/1975, pág. 54). Portanto, não basta uma enfermidade que se assemelhe à monstruosidade, 
“o enfermo pode não ser conforme à natureza, mas é de certa forma previsto pelo direito" (pág. 54). O monstro que interessa a Foucault é aquele que interroga o direito, colocando o sistema penal em xeque.

Henriette acaba por se transformar no próprio ganha pão da psiquiatria. “O personagem monstruoso, (...) constituirá o pão cotidiano da psiquiatria, de um lado, e da psicologia criminal, da psiquiatria penal, de outro" (pág. 93). Daquela lacuna não prevista no sistema jurídico-psiquiátrico, veremos surgir um saber essencial para a psiquiatria criminal. E, "não apenas para a história da psiquiatria criminal, mas também para a história da psiquiatria pura e simplesmente" (pág. 96).

Ora, e o que surge como ganha pão para a psiquiatria? Nada mais nada menos que a criação de um saber sobre os instintos sexuais. Na ausência do delírio, coube a psiquiatria investir sobre os instintos, "os impulsos, as pulsões, as tendências, as propensões, os automatismos" (Foucault, 2010/1975, pág. 112). Por isso, Foucault retoma a fala de Cornier no momento em que é presa: - "Eu sei que isso merece a morte". Ora, "por acaso isso não prova que o interesse que ela tinha, que todo indivíduo tem, de viver não foi forte o bastante para servir de princípio de bloqueio dessa necessidade de matar, dessa pulsão de matar (...)?" (pág. 110, grifo nosso).

Não por acaso, Fournier, advogado de Henriette, descreve o que compreendeu como um "instinto bárbaro" da cliente. Marc, o médico, afirma que se trata de um "ato instintivo" ou "propensão instintiva". Vê-se que se para a psiquiatria faltou o delírio, isso não significa que ela não possa fazer uso dos instintos. Onde escapou o delírio, reencontraremos o instinto como novo motor diagnóstico. "Toda a inscrição da psiquiatria na patologia evolucionista, toda a injeção da ideologia evolucionista na psiquiatria vai poder se fazer, não a partir da velha noção de delírio, mas sim a partir dessa noção de instinto" (Foucault, 2010/1975, págs. 113-114).

Foucault retoma o psiquiatra Heinrich Kaan como alvo e precipitador fundamental de suas críticas. Henrich Kaan é, portanto, aquele que permite compreender a junção entre o "instinto sexual e a fantasia 
ou imaginação" (Foucault, 2010/1975, pág. 246). Retomando o livro Psychopathia sexualis, de Kaan, escrito em 1846, Foucault (2010/1975) demonstra haver um desvio do ato natural pela inscrição da imaginação do instinto. "Como pode haver tal desvio em relação ao ato natural? Pois bem, o fator do desvio é a imaginação, é o que ele chama de fantasia, a imaginação mórbida" (pág. 245).

Mais do que à psiquiatria, Foucault se endereça igualmente à psicanálise na medida em que ele passa a abordar os instintos sexuais. Ainda que sua crítica se direcione em um primeiro momento a Kaan, o alvo mais abrangente é sem dúvida a teoria de Sigmund Freud. Percebam que tentar se esquivar da crítica foucaultiana, demonstrando que o instinto sexual se refere à biologia, enquanto a pulsão freudiana corresponderia a outro registro, é apenas contraproducente e pouco profícuo para que a psicanálise avance.

É comum ouvirmos a desqualificação da crítica de Foucault por uma espécie de equívoco nominalista, no qual o filósofo denunciaria a psicanálise pela compreensão de instintos sexuais, sendo que esta teoria teria insistido na dimensão da pulsão. Observemos, porém, que ao propor a imaginarização do instinto, o próprio Foucault evita uma interpretação biológica deste. Portanto, veremos que se a psicanálise deseja dialogar, respondendo à crítica de Foucault, ela deve partir de outro pilar. Assim sendo, reiteramos a relação entre o monstro sexual e o instinto sexual segundo a perspectiva da criança perversa polimorfa de Sigmund Freud.

\section{A criança perversa polimorfa e o Marques de Sade}

No escrito $O$ anormal, Foucault retoma a psiquiatria de Henrich Kaan, mas isso não impede que possamos ampliar sua crítica à psicanálise. Na realidade, diremos que pela potência do discurso psicanalítico, a psicanálise se torna o grande objeto de crítica para a teoria dos anormais de Michel. Ao demonstrar o "monstro sexual" (Foucault, 2010/1975, pág. 52) como genealogia do anormal, Foucault se aproxima sobretudo da criança perversa polimorfa, presente nos escritos de Sigmund Freud. 
No escrito "Três ensaios sobre a teoria da sexualidade", Freud (1996/1905) apresenta-nos a pulsão sexual a partir de uma ampliação da sexualidade. A partir das primeiras experiências de satisfação, Freud interpreta que se inscreveriam traços de satisfação no qual a criança busca retornar, o que corresponde à ampliação das zonas erógenas e objetos de satisfação. Certamente, tal compreensão não é possível sem que a noção de prazer se apresente como aquela que reativa a busca pela satisfação perdida. "Está claro, além disso, que o ato da criança que chuchuca é determinado pela busca de um prazer já vivenciado e agora relembrado" (pág. 171).

Freud descreve a perversão como o momento presente na vida infantil pelo qual a criança busca prazer auto-erógeno como objetos infantis. "Agora se nos oferece a conclusão de que há sem dúvida algo inato na base das perversões, mas esse algo é inato em todos os seres humanos, embora, enquanto disposição, possa variar de intensidade e ser acentuado pelas influências da vida" (pág. 162). Portanto, o autor apresenta-nos uma sexualidade desorganizada segundo a referência normativa dos objetos genitais.

Evidentemente, atribuir um objeto normativo à pulsão já representa um impasse enorme e gigantesco para a psicanálise, pois, Freud não cansou de descrevê-la como uma força que busca satisfação independentemente dos objetos. Sobre tal aspecto, Van Haute e Tomas Geyskens (2017) propõem que tomemos uma psicanálise sem Édipo, pois haveria nesse conceito a normatividade do sexual, o que é representa, para os autores, uma hipótese que se opõe ao conceito de pulsão e a bissexualidade em Freud. "Portanto, no trabalho de Freud, há uma tensão entre o complexo de Édipo e disposições bissexuais compartilhadas por todos nós" (Haute \& Geyskens, 2017, pág. 186). Longe de ignorarmos a crítica de Haute e Geyskens, seguiremos uma empreitada que se apresenta mais próxima dos ensejos de Sigmund Freud e, sobretudo, do diálogo propiciado por Foucault. Retomaremos a relação entre o Édipo e a psicopatologia em breve.

É inevitável dizer que ao mesmo tempo que Freud menciona a bissexualidade do ser humano como condição inerente e decorrente da pulsão, ao mesmo tempo o autor nos apresenta a perversão da 
sexualidade como aquela que se atrela de imediato ao polimorfismo dos objetos. Daí a presença do seio, das fezes como objetos parciais de satisfação. Ao formalizar a perversão polimorfa como uma fase comum da infância, Freud juntamente apresenta-nos a sua primazia na vida adulta como patológica. Desse modo, a universalidade da perversão polimorfa, na infância, torna-se uma patologia na vida adulta. "Com a chegada da puberdade introduzem-se as mudanças que levam a vida sexual infantil a sua configuração normal e definitiva" (Freud, 1996/1905, pág. 196).

É verdade que Freud mencione que na vida adulta prevalecem os rastros da sexualidade infantil. Por isso, não se pode dizer que Freud alude o completo aniquilamento da sexualidade primitiva na vida adulta. "Na verdade, acostumamo-nos a atribuir a todo ser humano civilizado certa quantidade de repressão e impulsos perversos, determinada cota de erotismo anal, de homossexualismo e assim por diante (...)" (Freud, 1996/1912, pág. 267). À vista disso, temos a presença de uma erótica ligada aos objetos primitivos da primeira infância.

Na realidade, trata-se da ênfase dada aos objetos primitivos, isso é, da "quantidade" (pág. 271) de investimento conferida a um representante psíquico. É pela primazia desses investimentos quantitativos da libido que veremos o investimento de uma regularidade universal da vida infantil se tornar uma irregularidade da sexualidade. Ora, é da normalidade na vida infantil para a anormalidade na vida adulta, no paradoxo da sexualidade perversa polimorfa, que encontraremos o paradoxo do monstro. Para Foucault, "o monstro é, por definição uma exceção; o indivíduo a ser corrigido é um fenômeno corrente. É um fenômeno tão corrente que apresenta - e é esse seu primeiro paradoxo - a característica de ser, de certo modo, regular na sua irregularidade" (Foucault, 2010/1975, pág. 49).

É exatamente da aproximação do monstro sexual com a criança perversa polimorfa que Sade se torna o personagem exemplar, para Foucault. "O monstro moral eclode, na literatura, com o romance gótico no fim do século xviII. Eclode com Sade" (Foucault, 2010/1975, pág. 64). Sabe-se que Sade foi encarcerado por diversas vezes durante 
sua vida. Em 29 de outubro de 1763, Sade é preso em Vincennes por uma lettre de Chachet- "carta com o timbre real ordenando a prisão ou o desterro de uma pessoa sem julgamento" (pág. 32). Ora, do que se trata esse objeto? Foucault (2010/1975) menciona que a carta possui o mesmo tipo de discurso utilizado pelos psiquiatras. Trata-se ao fim de evitar a perversidade e o perigo.

A lettre-de-cachet não era uma lei ou um decreto, mas uma ordem real a uma pessoa. Tal objeto poderia obrigar uma pessoa a se casar ou, como salienta Foucault (2013/1973), na maior parte das vezes, esse objeto servia como instrumento de punição. "Podia-se exilar alguém pela lettre-de-chachet, privá-lo de alguma função, prendê-lo" (pág. 95). Assim, a lettre-de-cachet foi utilizada para lidar com condutas de imoralidade - devassidão, sodomia, bebedeira e adultério. Sade foi a amostra exemplar e paradigmática de que o ser do acusado passou a ser julgado não tanto pelo seu ato, mas essencialmente pela tipificação moral que viria a anteceder o próprio crime.

No encontro entre o monstro e o sexual, veremos surgir a figura do anormal como nova categorização da psiquiatria moderna - seu diagnóstico. Sade é assim assimilado pelo sistema jurídico-psiquiátrico de modo semelhante àquele empregado no caso de Henriette Cornier: pela inclusão de um saber-verdade sobre o instinto sexual. Um saber sobre o instinto que permite formalizar uma tipologia do sujeito suficiente para antecipar o crime.

\section{A criança masturbadora e o incesto epistemofílico}

Na aula de 5 de fevereiro de 1975, Foucault retoma a temática do monstro em King Kong para descrever a semelhança com os pequenos bichos-papões monstruosos que acabam por devorar seus pais. É verdade que Foucault em referência ao conto de Charles Perrault, Pequeno polegar dos Contos da mamãe ganso retome a história a partir dos monstros (bichos-papões), no entanto, ele o faz de modo muito mais abrangente ao se direcionar aos pequenos perversos polimorfos 
que acabam por devorar seus genitores, dando a entender o desejo edipiano dos nossos pequenos. E mais, Foucault não apenas retoma a perversão polimorfa na infância edipiana, mas também a partir da criança masturbadora. Façamos uma breve elucidação da relação entre a masturbação e a criança perversa polimorfa para, em seguida, demonstrarmos em que medida veremos o desejo edipiano.

A masturbação foi compreendida como causa de diversos sintomas somáticos e psíquicos em meados do século XVIII. Meningites, encefalite, mielite, tuberculose eram doenças que foram explicadas pela presença patológica na vida adulta ainda que a etiologia fosse encontrada apenas nos atos praticados durante a primeira infância. Assim, ela se torna predominantemente um objeto da ciência psiquiátrica. Aqui, veremos sobretudo a presença da masturbação como patologia clínica e não tanto como fissura moral. Portanto não se trata de uma falta moral, mas da patologia. "Não é com uma vida adulta perdida de depravação e de vício que se ameaçam as crianças, quando se impede que elas se masturbem, mas com uma vida adulta tolhida pelas doenças" (Foucault, 2010/1975, pág. 206).

Sabe-se que o próprio pensamento de Freud (1912/1996) não escapou à patologização decorrente da masturbação. No escrito "Contribuições a um debate sobre a masturbação" o autor reafirma a masturbação como causa das neuroses atuais. Notemos que não se trata de um texto incipiente para a psicanálise freudiana. $\mathrm{O}$ psicanalista reafirma o que dissera anos antes ao mencionar que a masturbação poderia levar à descarga insuficiente da sexualidade, ocasionando uma patogenia. "Assim também persiste a possibilidade de que sejam precisamente essas peculiaridades da atividade masturbatória os veículos de seus efeitos patogênicos" (pág. 269).

Ora, mas qual a relação entre a masturbação e o Édipo para Freud? Façamos primeiro o percurso para o psicanalista para posteriormente retomarmos a crítica de Foucault. No escrito "A dissolução do complexo de Édipo", Freud (2011/1924) observa que a masturbação num primeiro momento tem o intuito de uma "descarga genital da excitação sexual própria do complexo, e em todas as épocas posteriores deverá sua importância a tal relação" (pág. 208). Porém, 
podem interpretar a letra de Freud para dizer que aquele objeto que, antes representava apenas a descarga de excitação, ganha igualmente a possibilidade de cifrar o desejo do outro. Freud vai observar que a criança se vê encantada pela mãe, desejando dar a ela o objeto do seu desejo. Nesse momento, ela agita o seu órgão, endereçando-se à figura materna. O órgão, de extremo prazer para a criança, torna-se assim a possibilidade de cifrar o desejo desse primeiro outro.

Diante da masturbação, a mãe pode ela mesma repreender a criança, mas Freud diz que há uma insuficiência das ameaças. Além do mais, a mãe mantém uma relação dúbia com a criança. Por um lado, ela valoriza o membro da criança por outro desvaloriza mencionando ser esse objeto uma grande porcaria. Pois bem, sem desejar resolver absolutamente a charada sobre os fatores que levam à dissolução do complexo de Édipo, Freud menciona o momento em que a criança se depara efetivamente com o órgão castrado de uma outra criança. Aí, as ameaças de castração, anteriormente ignoradas, ganham sua potência. Nesse momento, o pai assume sua função castradora, sendo tomado como um rival (aquele que possui o órgão) responsável pela mutilação da criança.

Assim, temos a tendência à abdicação da mãe como possibilidade de preservar o órgão sexual contra o pai tirânico e castrador. Esse é o instante em que a criança, para preservar o pênis, afasta-se da mãe, abdicando dos desejos amorosos a ela investidos, o que corresponde ao momento em que o complexo de Édipo encontra sua dissolução. $\mathrm{O}$ órgão preservado, porém, não permanece sendo agitado, ele entra em estado de latência, momento em que veremos a queda da atividade masturbatória. Eis o modo como a repressão do incesto se correlaciona à repressão da masturbação.

Para o caso de a criança não abdicar da masturbação, veremos a presença de toda uma gama de desejos edipianos fixados à figura materna e aos objetos primitivos da vida infantil. Portanto, ainda que a masturbação seja comum e universal na vida infantil (auto-erotismo), sua prevalência em detrimento da sexualidade heteroerótica, corresponde a modos de fixação infantil que denotam certa anormalidade da sexualidade. 
Pois bem, nos Anormais, Foucault vai se dirigir à psicanálise de modo crítico, buscando deslocar a centralidade e universalidade do Édipo freudiano para uma contingencialidade que visa produzir, na realidade, uma tecnologia dos instintos. "Tivemos, em face da eugenia, a outra grande tecnologia dos instintos, o outro grande meio que foi proposto simultaneamente, numa sincronia notável, a outra grande tecnologia da correção e da normalização da economia dos instintos, que é a psicanálise" (Foucault, 2010/1975, pág. 114).

Ora, e de que modo Foucault realiza essa empreitada? Diremos que a partir da historicização da figura do masturbador. Foucault tomou fundamentalmente de modo problemático a relação entre a masturbação e o desejo incestuoso. Para ele, a masturbação do órgão não advém inicialmente de desejos primitivos e incestuosos da criança. Foucault reserva ao início do ato masturbatório a dimensão do acaso. Se por um "comichão", excitação que resultante "de uma leva fricção", ou ao "acaso, gesto aleatório, puramente mecânico", nada sugere que tenhamos a masturbação atrelada ao desejo incestuoso.

Na realidade, Foucault localiza a sedução do adulto como origem do ato masturbatório. Nas famílias burguesas, os educadores, as babás, os domésticos, os professores e preceptores se tornam causadores da masturbação - "Simplesmente porque não há (...) causalidade endógena da masturbação” (Foucault, 2010/1975, pág. 211). É devido ao fato de os pais não quererem cuidar diretamente de seus filhos, que há o fenômeno da masturbação como efeito do abuso sexual cometido pelos serviçais da casa. Temos assim uma causa externa: "desejo dos adultos pelas crianças, eis a origem da masturbação" (pág. 212). Aqui, porém, ainda não vemos o desejo incestuoso, mas o desejo pelo adulto na medida em que o adulto o deseja.

Com intuito de evitar a masturbação, pois, trata-se de um movimento causador de inúmeras patologias, vemos surgir no século XIX toda uma modificação física do espaço familiar, uma nova organização na qual os intermediários serão suprimidos dos cuidados das crianças. Nesse momento, os pais se tornam os grandes vigilantes dos corpos de seus filhos. Eis a razão pela qual o desejo dos filhos 
passa a se manifestar como edípico, pois, os pais assumem o lugar de fiscalizar os corpos infantis, atestando de que as crianças não se masturbam. Por consequência, produzem o desejo incestuoso na cena familiar. "Deve-se dormir ao lado do jovem masturbador para impedi-lo de se masturbar, dormir no mesmo quarto e, eventualmente, na mesma cama" (Foucault, 2010/1975, pág. 215).

Desse modo, Foucault menciona que a psicanálise se torna uma tecnologia que passa a gerir a sexualidade, reinserindo o desejo incestuoso no seio da família. É bem verdade que ainda que a psicanálise reinsira o desejo edipiano na família, isso não significa que não tenhamos tido "esta outra operação, igualmente real, que consistiu em retirar a criança da família em consequência do medo do incesto adulto" (Foucault, 2010/1975, pág. 239). Desse modo, a psicanálise não inventa propriamente o Édipo, mas passa a administrá-lo e reinseri-lo como desejo universal. Diremos com Foucault que a psicanálise não inventa o Édipo, ela torna-se um efeito do Édipo para, posteriormente, gerir a sexualidade como uma tecnologia das pulsões.

Para o filósofo, antes de mais nada, trata-se de pensar a psicanálise como uma tecnologia que cria o saber da pulsão para lidar com o incesto epistemofílico. Posteriormente, esse saber passa a compreender a masturbação como manifestação edípica da criança. Eis a genealogia de Foucault: demonstrar que o monstro sexual e o masturbador encontram-se como personagens precipitantes dos anormais na medida em que se tornam casos paradigmáticos para localizar os instintos sexuais.

Ao reinserir o Édipo na análise, a psicanálise passa a ser, para Foucault, compreendida como um instrumento de limitação, contenção e coação do desejo na medida em que os psicanalistas fazem o desejo entrar em uma estrutura familiar definida à priori. Para o filósofo, "Édipo (...) não é o conteúdo secreto de nosso inconsciente, mas a forma de coação que a psicanálise tenta impor na cura a nosso desejo e a nosso inconsciente. Édipo é um instrumento de poder (...)" (Foucault, 2013/1973, pág. 38). Vejamos do que se trata a emblemática afirmação de Foucault. 


\section{O Édipo de Foucault a Freud: poder, saber e verdade}

Anteriormente descrevemos que Édipo Rei não deve ser compreendido como um complexo de representações inconscientes universais. Isso porque Foucault localizou o complexo edípico como uma estrutura de desejos contingentes à família burguesa do século XIX e XX. Ora, mas se não se trata de um complexo desejos e representações inconscientes, o que dizer do édipo para Foucault? Aqui veremos novamente o discurso jurídico assumir seu lugar de interpretação para o francês: o discurso jurídico na medida em que há a investigação da verdade no crime cometido por Édipo.

Numa série de conferências ministradas no Brasil em 1973, Foucault retoma Édipo Rei ressaltando o seu interesse pelo mito grego. Publicadas no livro A verdade e as formas jurídicas, veremos Foucault reiterar que não há, na tragédia de Sófocles, um complexo de representações cuja centralidade seja o incesto e o parricídio. "Se existe complexo de Édipo, ele se dá não ao nível individual, mas coletivo; não a propósito de desejo e inconsciente, mas de poder e de saber. É esta espécie de complexo que eu gostaria de analisar" (Foucault, 2013/1973, pág. 39).

Antes de rechaçarmos a leitura de Foucault, busquemos compreender o que o autor nos apresenta. Evitemos o erro cometido naquela época. Sabe-se que durante suas apresentações, Foucault não apenas foi mal interpretado, mas, na realidade, pouco compreendido. Como escreve Eduardo Jardim (2013), no prefácio da quarta edição do livro, "pode-se notar no debate, depois das conferências, que nenhuma das intervenções revela compreensão do que se tinha escutado" (pág. 12).

Assim, Foucault esclarece que Édipo Rei de Sófocles não se refere a um discurso sobre o sexual e sobre o desejo, mas sua centralidade consiste essencialmente num discurso de poder. "Édipo é uma certa maneira do poder médico e psicanalítico se exercer sobre o desejo e o inconsciente" (2013/1973, pág. 38). Conforme demonstrado, o complexo de Édipo, para Freud, mantém a dimensão universalista en- 
quanto, para Foucault, corresponde apenas ao caráter contingencial da família de Viena. Desse modo, interpretar o desejo e a sexualidade segundo os moldes de Freud pode ser um limitador à potencialidade das instâncias desejantes. Na realidade, para Foucault, a história de Édipo representa um passo fundamental para a história da civilização, um passo rumo à separação do poder e do saber. Vejamos de que modo Foucault desenvolve seu argumento.

Foucault ressalta que na busca judiciária pela verdade, o litígio ou contestação de uma das partes se dirigia aos deuses. Seu exemplo partiu da contestação entre Antíloco e Menelau durante os jogos que se realizaram na ocasião da morte de Pátroclo. Nesse episódio, os dois participavam de uma corrida de carros, no qual Antíloco venceu Menelau. Após encerrada a corrida, Antíloco é acusado pelo último como trapaceiro. O interessante desse episódio é que mesmo havendo um terceiro, responsável por observar o andamento correto da corrida, não se recorreu a ele como testemunha. Pelo contrário, na busca pela verdade, jurou-se à figura de Zeus. Menelau lançou um desafio: "Põe tua mão direita na testa do teu cavalo; segura com a mão esquerda teu chicote e jura diante de Zeus que não cometeste irregularidade" (Foucault, 2013/1973, pág. 40).

Foucault observa que, na Grécia arcaica,havia a busca da verdade jurídica como algo semelhante a um "jogo de prova". No "jogo de prova", a verdade encontra-se atrelada ao poder e Zeus é aquele que possui a verdade sobre o inquérito. Portanto, ainda que se tenha uma testemunha do ocorrido, não se recorre àquele que viu o acontecimento com seus próprios olhos, mas, sim, à verdade a partir de um juramento aos deuses. Pois bem, distanciando-se do jogo de prova, Sófocles dá um passo adiante na história, pois, a "tragédia de Édipo se fundamenta em um mecanismo inteiramente diferente" (2013/1973, pág. 41). Vejamos de que modo tal mudança é possível.

Sabe-se que a tragédia de Sófocles se inicia pela busca do assassino de Laio. Foucault então demonstra haver três momentos, o que aqui tomaremos enquanto três séries distintas. Primeiramente, quando a investigação jurídica se dirige aos deuses, pergunta-se a Apolo: "quem foi assassinado?" A resposta é: Laio. Então, pergunta-se: 
"quem o assassinou". Momento em que Apolo se recusa a responder, sendo seu saber marcado por uma incompletude. Pois bem, veremos em seguida o adivinho Tirésias ser questionado. Muito próximo de um Deus, Tirésias responde, dando a conhecer a outra metade da verdade: "Foste tu quem matou Laio". Desde a fala de Apolo e Tirésias tudo está dito e representado.

No entanto, Foucault observa que Tirésias não diz efetivamente quem matou Laio - "Foste tu que matou Laio", mas: "Prometeste banir aquele que tivesse matado; ordeno que cumpras teu voto e expulses a ti mesmo" (Foucault, 2013/1973, pág.42). Eis a forma prescritiva e profética que é característica ao mesmo tempo do oráculo e adivinho. Foucault salienta que "tudo isso foi dito na forma do futuro, da prescrição, da predição; nada se refere à atualidade do presente; nada é apontado" (2013/1973, pág. 43). Daí a presença de outros dois tempos como insistência na peça, o que nos demonstra a insuficiência da primeira série.

O filósofo chama atenção para uma segunda série, àquela que se refere à buscar a verdade no passado e presente. "Precisamos agora do presente e do testemunho do passado: testemunho presente do que realmente aconteceu" (Foucault, 2013/1973, pág. 43). Aqui, encontramos não mais a figura de duas divindades, mas a presença de dois reis. Primeiro a testemunha de Jocasta que, buscando livrar Édipo de sua culpa, disse: "Vês bem que não foste tu, Édipo, quem matou Laio, contrariamente ao que diz o adivinho. A melhor prova disso é que Laio foi morto por vários homens no entroncamento de três caminhos" (Foucault, 2013/1973, pág. 43). Momento em que Édipo pronuncia: "Matar um homem no entroncamento de três caminhos é exatamente o que eu fiz; eu me lembro que ao chegar a Tebas matei alguém no entroncamento de três caminhos" (Foucault, 2013/1973, pág. 43). Temos aqui uma verdade quase completa. Não se tornou de toda completa porque faltou saber se Laio foi morto por um homem ou por vários homens.

$\mathrm{Na}$ incapacidade de responder à questão, busca-se uma outra verdade que possa dizer sobre o assassino. Busca-se saber se Laio é pai de Édipo. Veremos então a presença da terceira série como nova confrontação com a verdade e esperança do herói. “O que falta é exa- 
tamente o que lhes dá uma espécie de esperança, pois o deus predisse que Laio não seria morto por qualquer um, mas por seu filho" (Foucault, 2013/1973, pág. 43). Portanto, enquanto não se provar que Laio é pai de Édipo, não saberemos quem matou Laio.

Nesse instante, veremos entrar em cena dois escravos, duas testemunhas. Primeiro o escravo de Corinto. Como testemunha, esse confirma, lançando contra Édipo essas duras palavras: "Políbio não era teu pai" (Foucault, 2013/1973, pág. 44). Por fim, ao convocar o escravo do Citerão, última testemunha, dá-se sobre a cabeça de Édipo uma última pancada: "Com efeito, dei outrora a este mensageiro uma criança que vinha do palácio de Jocasta e que me disseram que era seu filho" (2013/1973, pág. 44), confirmando, assim que Édipo não fora morto quando bebê, mas adotado. "Podemos dizer, portanto, que toda a peça de édipo é uma maneira de deslocar a enunciação da verdade de um discurso de tipo profético e prescritivo a um outro discurso, de ordem retrospectiva, não mais da ordem da profecia, mas do testemunho" (Foucault, 2013/1973, pág. 46).

Ora, é do mais humilde escravo e do mais simples dos pastores que a verdade vem se enunciar. Certamente, devemos salientar que a verdade de Apolo e Tirésias é em certa medida ignorada ou insuficiente. Tal fato nos conduz à empreitada de Sófocles: tornar a busca pela verdade jurídica dependente de um olhar "empírico e quotidiano" (Foucault, 2013/1973, pág. 46), no qual veremos a separação entre o poder e o saber. Assim, pelo tempo presente e passado, o escravo testemunha, pelo seu saber, a verdade.

O saber que se encontra do lado do escravo, não mais se tratando da figura de um Deus ou Rei. Édipo é, assim, desbancado do lugar de saber, pois, ele é aquele que sabia demais ao início da peça e gradativamente, pela busca da verdade, foi se tornando um homem arruinado pela condição de um não-saber. "Aquele que unia seu saber e seu poder de uma certa maneira condenável e que a história de Édipo devia expulsar definitivamente da história" (Foucault, 2013/1973, pág. 47).

Eis a verdadeira tragédia de Édipo para Foucault - a separação do saber e poder. Afinal, matar o pai não é tanto o destino de Édipo 
como é o de Laio em ser morto pelas mãos de seu filho. Laio é o homem que após estuprar Crisipo foi condenado pela predição de um oráculo a ser morto pelas mãos de seu próprio filho. Daí, o trágico pertencer mais ao pai do que ao filho assassino. Como salienta Foucault, o título da peça não é "Édipo, o incestuoso nem Édipo, o assassino de seu pai, mas Édipo-Rei" (2013/1973, pág. 48). A tradução para o português e francês, como bem observa Foucault, é inexata. Na realidade, trata-se Oidípous Tyrannos - "Édipo todo poderoso" (pág. 50). Essa tradução coloca em jogo o poder de Édipo, poder que a ele cabia inicialmente por sua união ao saber.

Interpretando Foucault, permitimo-nos retirar algumas consequências para a psicanálise. Pelo complexo de Édipo, Freud postula supostamente o pai como aquele que está no lugar de poder, mas ele não se encontra como o saber do sexual. Na construção freudiana, pode-se inferir que ao matar o pai, a criança obtém o gozo sexual com a mãe. No entanto, na peça de Sófocles, não se trata de matar o pai e tomar a verdade do desejo materno. Édipo se deita com a mãe não pelo parricídio do pai, mas sim pela decifração do enigma da esfinge. Logo, é pelo saber que se toma a mãe, cometendo o ato incestuoso.

O pai ocupa supostamente o lugar de poder, mas o sexual se encontra em outro lugar - no saber da esfinge. Aqui, apesar de separarmos saber e poder, ainda mantemos o saber atrelado à verdade. Até o ponto em que nos encontramos, a psicanálise se mantém como uma tecnologia das pulsões na medida em que administra as pulsões sexuais. "A psicanálise participa do dispositivo de sexualidade ao fixar a verdade do sujeito na enunciação contínua e repressiva de seu próprio desejo sexual" (Dunker \& Kyrillos-Neto, 2015, pág. 147). Portanto, é necessário dar um passo a mais.

Para pensarmos na subversão dessa hipótese, Freud será nosso próprio guia. Ao reler o complexo de Édipo, pela presentificação do conceito de pulsão de morte, o psicanalista permite que retomemos uma nova divisão: não a divisão do poder e saber, mas divisão entre saber e verdade. Não se trata do saber-verdade das pulsões sexuais, mas de um saber sobre o sexual no qual a verdade faz furo. Pela pulsão de morte, vemos que Freud realiza uma inversão de Sófocles no 
qual a verdade passa a advir não pela empiria e experiência do escravo-testemunha, mas fundamentalmente da ausência de toda e qualquer testemunha como portadora da verdade. Em outras palavras, a pulsão de morte é assim anterior à testemunha de todo e qualquer saber advindo da experiência.

No escrito "O seminário sobre 'A carta roubada'”, Jacques Lacan (1998/1955) retoma à relação entre saber, poder e verdade, não tanto pela testemunha do presente e passado, mas sobretudo na medida em que descrevemos o tempo futuro. Sabe-se que no conto de Poe (1999) - A carta roubada -, a missiva surrupiada passa de mão em mão, mas sem que seja efetivamente utilizada. $\mathrm{O}$ ministro rouba a carta bem diante dos olhos da rainha, sabendo que aquele objeto não pode vir a ser utilizado, pois, nesse caso, ele mesmo enfrentará os resultados danosos de sua traição. "É que ao observar, como faz o narrador desde a primeira conversa, que com o uso da carta/letra dissipa-se seu poder, percebemos que essa observação só visa seu uso, justamente, para fins de poder" (Lacan, 1998/1955, pág. 35).

Ora, mas porque nos interessa tal conto? Lacan se remete à novela de Poe (1999) com intuito de reler sobretudo o funcionamento estrutural do Édipo. No conto, observamos a separação entre saber e poder, pois a carta jamais se mostra em seu sentido. Esse é exatamente o que permite que ela dê poderes ao Ministro na medida em que ele não a utiliza. Pelo significante puro, isso é, pela opacidade de sentido da carta, a verdade se inscreve como sem sentido - nonsense - ao saber. Temos uma relação semelhante entre a pulsão e o inconsciente - a pulsão de morte como impossibilidade radical ao saber dos significantes predicativos.

Pela interpretação lacaniana do mito de Freud, a verdade passa a circular justamente porque há uma promissória de gozo, de saber futuro, que jamais pode vir a ser desvelada/descontada. Assim, junto à verdade, o poder circula na medida em que não se pode à carta atribuir um sentido ou saber. "Os escritos carregam ao vento as promissórias em branco de uma cavalgada louca. E, se eles não fossem folhas volantes, não haveriam letras roubadas, cartas que voaram" (Lacan, 1998/1955, pág. 30). 
Notemos que Lacan buscou retirar o poder da fixidez atribuída a um personagem. Essa perspectiva permitiu que o poder circule nas seriações da Carta roubada, pois, na realidade, o poder encontra-se do lado do artefato, da missiva. Isso porque o poder carrega a verdade pelo ilusionismo de sua ficção. "Seria mesmo o cúmulo do que poderia atingir o ilusionista fazer-nos verdadeiramente enganar por um ser de sua ficção" (pág. 23). Assim, o poder-verdade apresenta-se como promissória, que circula sem estar fixo a uma deidade ou rei. É o que permite dizermos que para um primeiro momento, o ministro é aquele que tem o poder - na medida em que surrupia a carta da rainha e a esconde sem utilizá-la -, e após presenciar o retorno de seu ato sobre si, tendo a missiva igualmente roubada, vê o poder trocar de mãos, instalando-se ao lado do detetive Dupin (até então considerado um amador).

Observemos que para Édipo Rei, o verdadeiro trágico se encontra não tanto na dissolução do saber-poder, mas na dissolução do saber-verdade. Édipo decifra a esfinge, livrando a cidade de Tebas da peste que a assolava, mas a cidade é novamente tomada por uma pestilência. Temos assim a repetição da peste como a repetição do enigma ou repetição da figura da esfinge - enigma semelhante àquele posto de maneira invertida pela criança à mãe: o que queres?

Para a esfinge-mãe, não se trata tanto do desejo incestuoso de Édipo por Jocasta, mas do desejo de Jocasta pelo filho. Na realidade, diremos que se trata mais do gozo dessa mãe , pois, do gozo não há objeto ou saber que possa a vir nomear. Essa é uma mãe que sabia desde o início com quem se deitava, permitindo que toda trama se desenrolasse bem abaixo de seu nariz. Como Salienta Quinet (2015), na fatídica encruzilhada, um dos servos que acompanhava Laio sobreviveu, tornando-se a única testemunha do massacre perpetrado por Édipo. Fugitivo da cena trágica, deslocou-se diretamente da encruzilhada para a presença da rainha, contando-lhe todo o ocorrido. Assim, quando Édipo busca conhecer a verdade jurídica de seu próprio crime, vemos a curiosa advertência de Jocasta: "Melhor não saber quem você é".

A testemunha nesse caso não é suficiente para trazer a verdade que interrompa o gozo da mãe. Porém, ainda que não possamos dizer 
que a testemunha entrave o mortífero de Jocasta, é na medida em que ela ignora a testemunha, distinguindo-se daquele que não sabe, que o mortífero ganha seu lugar. É preciso que exista uma testemunha para que se possa inscrever o mortífero. Assim, o mortífero da pulsão exige o testemunho de que Jocasta "tudo sabia" e ainda assim agiu como se nada soubesse.

Conforme Freud pôde salientar no escrito "Além do princípio de prazer", a pulsão de morte é atravessada pelo saber da experiência apenas na medida em que se mostra num mais além desse saber. Afinal, se Freud propôs tardiamente a pulsão de morte, isso foi porque a pulsão de morte só pôde advir para o psicanalista como um além do princípio de prazer. Ou seja, ela não é constada por si senão pelo esgotamento de todas as demais explicações dadas pelo princípio de prazer e seus embates com a realidade. Em suma, é só quando se ausentam as explicações que a pulsão de morte se torna uma suposição pela repetição compulsiva que lhe é inerente. A compulsão à repetição como marca de uma negatividade ao saber - "enfim, ainda restam tantos aspectos sem explicação, que a formulação da hipótese da compulsão à repetição se justifica". (Freud, 2006/1920, pág. 148).

Notemos que é na impossibilidade ao saber que Freud investe o conceito de pulsão de morte. Frente ao impossível de decifrar - a verdade da morte -, Édipo passa a ser devorado não pela falta de saber, mas porque ousou saber daquilo que não há saber. A peste persiste como a inconsistência de um saber que ousou decifrar o indecifrável. Édipo Rei parece enunciar que o saber, na realidade, deve ser desvinculado da verdade, e só, nessa condição, torna-se capaz de se separar efetivamente de todo e qualquer poder.

Assim sendo, para psicanálise freudo-lacaniana, retomar o Édipo nos moldes de uma teoria que pressupõe a normatização do sujeito é impossível, pois, o mito do Édipo acaba por deflagrar que não há, em sua radicalidade, saber regulador do sexual. A verdade é sempre anterior ao testemunho das normas sociais (impostas sobre a sexualidade). É só porque a verdade antecipa a qualquer relação de causa empírica, que o conceito freudiano de pulsão reaparece como uma força inabalável e incessante. 
Pela insistência da pulsão, é impossível pressupor qualquer tipo de adequação ou normalização do sujeito, pois, do pulsional não se pode atribuir um objeto fixo ou pré-determinado. Há no conceito de pulsão freudiana a insistência de uma força inabalável a todo e qualquer saber ou objeto prescrito pela norma social e civilizatória. Deste modo, a psicanálise permite ensaiar seu desvencilhamento da lógica de poder-saber presente no discurso do direito e da psiquiatria, pois, para Lacan, trata-se de insistir na impossibilidade de tomar a pulsão como saber, isso é, insistir na dimensão do sujeito como verdade.

\section{A pulsão de morte e o patológico}

No livro Os anormais, Foucault (2010/1975) se direciona à psicanálise como uma tecnologia das pulsões, responsável por aprisionar o desejo ao complexo edipiano. Nesse sentido, o analista reinsere o desejo edípico ao mesmo tempo em que exerce o lugar normativo sobre a sexualidade. Para o filósofo, o analista se posta como aquele que deve desvincular a criança de seus investimentos primitivos, elevando a sexualidade à normalidade. No entanto, ao mesmo tempo que vemos a proposição de uma normatividade dada pela travessia do complexo edípico, é a própria pulsão sexual que se aproxima do patológico.

Foucault (2010/1975) descreve que o conceito de instinto sexual surge juntamente a uma série de questionamentos que levam à problematização do normal e do patológico. São essas algumas das questões apresentadas pelo autor: é patológico ter instintos? Dar livre curso aos instintos, deixar agir o mecanismo dos instintos, é uma doença ou não é uma doença? É possível agir sobre os instintos? É possível corrigir os instintos? Ora, é inegável que esses questionamentos se encontrem na obra freudiana. Desse modo, veremos o próprio inconsciente como a marca do incurável.

No escrito "A dissolução do complexo de Édipo", Freud (2011/1924) menciona que não devemos apenas reprimir os desejos edípicos, mas destruí-los. "O processo descrito é mais que uma repressão, ele equivale, quando realizado de maneira ideal, a uma 
destruição e abolição do complexo" (pág. 209). Tomemos a distinção entre "destruição" e "repressão" para melhor contextualizarmos a questão.

Freud menciona a necessidade da destruição dos conteúdos edípicos, demonstrando que se trata de uma operação distinta do recalcamento dos desejos - caso tomemos a similaridade entre recalque e repressão. Portanto, a similaridade entre recalque e repressão nos aproxima da hipótese de que, sem a destruição, encontramos unicamente uma saída patológica do Édipo, isso é, de sua não dissolução completa. Há algo na dimensão do próprio recalcado que acaba por condicioná-lo à dimensão do patológico.

Desse modo, Dunker (2011) salienta que estamos na esfera de um inconsciente como sucedâneo do patológico. Neste aspecto, veremos a tentativa de certo distanciamento da psicanálise em relação à medicina na medida em que o sentido do patológico é reconsiderado. Não se trata de tomar a cura psicanalítica como o restabelecimento de um estado anterior. "Restabelecer-se, estabelecer-se novamente, voltar ao ponto em que se estava estabelecido, é uma ideia que liga, originariamente, o adoecer com a experiência de perda de lugar" (pág. 25). Pelo contrário, a psicanálise, primeiramente deve estudar o patológico para depois encontrar o normal.

Logo, devemos relativizar o conceito de normal e patológico para Freud, tendo em vista uma definição não essencialista ou meramente dogmática. Não se deve considerar o normal como um estado anterior (corpo saudável) no qual se busca retornar. A compreensão de normalidade não está à priori, sendo definida apenas de modo retroativo. "Nesta operação o próprio sentido do patológico se altera. Há na psicanálise uma teoria psicológica geral, de aspiração universalista, mas esta é construída como uma espécie de corolário ou inferência, jamais deduzida do funcionamento psíquico normal à priori" (Dunker, 2011, pág. 43).

Tais alegações, todavia não parecem suficientes para revitalizar a psicanálise aos olhos de Foucault. $\mathrm{O}$ autor considera que tanto a psiquiatra quanto a psicanálise formalizam a psicopatologia moderna a 
partir de uma noção evolucionista. Uma noção que conforme o próprio Foucault explicita, decorre sobretudo da produção do conceito de instinto sexual. Temos a psicanálise como "outra grande tecnologia da correção e da normalização da economia dos instintos" (Foucault, 2010/1975, pág. 114), ainda que, nesse sentido, possamos estabelecer o normal numa relação de posterioridade ao patológico. Assim sendo, mesmo ao postular o patológico de modo não essencialista, a psicanálise, pela pulsão sexual, permite, para Foucault, normatizar o investimento da pulsão em objetos ditos civilizatórios. Uma espécie de direção ou domação da pulsão conforme os efeitos propiciados pela dissolução do complexo de Édipo.

Recusar a crítica de Foucault à psicanálise sem que consigamos contrapor a hipótese de que exista uma psicopatologia evolucionista em Freud, pouco permite avançarmos. Afinal, assemelhando-se à própria psicopatologia, a perspectiva moral em Freud nos governa a um ponto civilizatório não sexualizado (sublimação) ou tomado por uma normatividade dos objetos sexuais.

Talvez seja difícil para muitos de nós ter de renunciar à crença de que o ser humano possua uma pulsão que busca o constante aperfeiçoamento e que possibilitou que chegássemos ao atual nível de produção intelectual e de sublimação ética (...) A incansável necessidade de contínuo aperfeiçoamento que se observa em uma minoria de pessoas pode ser facilmente compreendida como consequência do recalque pulsional sobre o qual está edificado o que há de mais valioso na civilização humana. A pulsão humana jamais renuncia à sua completa satisfação, a qual consiste na repetição de uma experiência primária de satisfação. Todas formas substitutivas ou reativa, bem como as sublimações, são insuficientes para remover sua tensão contínua (Freud, 2006/1920, pág. 164).

Ora, pensar a psicopatologia junto à moral não é exatamente a premissa desenvolvida por Foucault ao demonstrar o surgimento do anormal? Se a psicanálise deseja responder às pertinentes considerações de Foucault, sua resposta deve se viabilizar a partir de torções internas e necessárias. Tal resposta, nos parece ser dada a partir do escrito "Além do princípio de prazer". No texto, há a possibilidade de pensarmos 
um outro viés de leitura, tendo em vista que a dimensão da pulsão de morte antecede à própria sexualidade, subvertendo assim a dimensão teleológica do sujeito. Portanto, é imprescindível notar que essa nova contextualização da pulsão antecede a qualquer tipo de normatividade ou perspectiva evolucionista demonstrada a partir do sexual.

Vemos uma verdadeira amplificação do diálogo psicopatológico na medida em que reabsorvemos o mortífero da pulsão pela conceituação do mal-estar. Dunker e Kyrillos (2015) retomam o mal-estar como nova figura do patológico. "Não indica algo transitório ou crônico e tratável (...), mas uma condição, uma maneira de estar no mundo" (pág. 209). O mal-estar nos remete ao que há de incurável na experiência humana e, enquanto incurável, não podemos mencionar qualquer evolução normativa desse conceito.

Observemos o que menciona Freud (1996/1930) no escrito “O mal-estar na civilização". O autor aponta-nos três fontes para o mal-estar: primeiramente, a ameaça externa do mundo, dada pela relação entre o homem e a natureza. Em seguida, a ameaça corporal na medida em que patologias e doenças encurtam a qualidade de vida, levando o ser à morte. Por último, as relações humanas na civilização. O curioso é que criação da civilização consegue, pelo avanço tecnológico e científico, aplacar as duas primeiras fontes de mal-estar, mas não consegue aplacar a última. Na realidade, a própria ciência ou evolução tecnológica, torna-se mensageira do mortífero intensificando o mal-estar.

Assim, Freud (1996/1930) retoma o evolucionismo da ciência para problematizar o fato de que ela não necessariamente aplaca o mal-estar. É possível que um homem viaje para encontrar sua esposa, utilizando do meio de transporte aéreo, ou que um filho passe a se comunicar com a mãe pela utilização de recursos tecnológicos, que antes eram inimagináveis, mas Freud destaca que, no fundo, encontramos o dissabor irônico na qual a própria tecnologia propiciou ou fomentou o distanciamento entre pessoas. Com ela passamos a cruzar os oceanos, nos deslocando para lugares cada vez mais distantes. Assim, a tecnologia parece aplacar aquilo que ela mesma parece trazer ou produzir. 
Portanto, há algo da divisão do sujeito, como salienta Marcia Rosa (2018), que independe ou antecede à relação de saber produzido como demanda médico-jurídica. Ao questionar a psicanálise pela presença maciça do saber disciplinador, Foucault parece colocar o analista como grande Outro precipitador da divisão do sujeito (desejo edípico) sem que exista efetivamente a possibilidade da psicanálise se ater à uma outra divisão, muito mais fundamental e substancial: à divisão causada pelos efeitos destrutivos da pulsão de morte. Cabe salientar que, para o caso do analista ser tomado supostamente como um grande Outro, precipitador da divisão do sujeito, a ele também veremos a possibilidade de fechar a fenda narcísica aberta pela pulsão de morte, o que corresponde a algo absolutamente impossível.

Na genealogia foucaultiana, fundada em uma lógica disciplinar, observamos como argumento central a existência onipotente e poderosa de um grande Outro (encarnado no psiquiatra, no legista, na família e, enfim, até no psicanalista!) que, ao ganhar muita consistência, acaba poupando o sujeito de se encontrar com sua própria divisão subjetiva, com o fato de que ele goza contra ele mesmo! (Rosa, 2018, pág. 328).

Isso permite-nos dizer que embora Freud tenha reinserido o desejo na família, pela via do incesto e parricídio, isso não impede que o analista acolha o sujeito por uma divisão muito mais fundamental e primitiva. É esse o passo dado pela psicanálise a partir do conceito de pulsão de morte: introduzir a pulsão como verdadeiro inegociável do mal-estar. O mal-estar enquanto "verdade incurável de um sintoma" (Dunker, 2011, pág. 40), não sublimável ou passível de normatividade.

Assim, pela noção de pulsão de morte ou mal-estar, Freud (1996/1916) permite reeditarmos a compreensão do ato delituoso e sua função psíquica. Vale lembrarmos que no escrito "Alguns tipos de caráter encontrados no trabalho psicanalítico", Freud ressalta que inúmeros crimes foram cometidos com intuito de localizar a culpa, dando a essa um objeto ao qual fixar-se. "O resultado invariável do trabalho analítico era demonstrar que esse obscuro sentimento de culpa provinha do complexo de Édipo e constituía uma reação às duas grandes intenções criminosas de matar o pai e de ter relações sexuais com a mãe". Em seguida, o psicanalista acrescenta: "Em compara- 
ção com esses dois, os crimes perpetrados com o propósito de fixar o sentimento de culpa em alguma coisa vinha como um alívio para os sofredores" (pág. 348).

Diferentemente da tese apresentada no escrito citado, podemos interpretar o conceito de pulsão de morte em Freud para dizer que a culpa se apresenta não tanto como um resto dos desejos infantis e primitivos, mas essencialmente como presença do mal-estar inerente ao ser humano. Assim, o crime é, em uma de suas vertentes, a nomeação do mal-estar causado pela pulsão de morte. A culpa é por assim dizer anterior a toda causa advinda pelo romance edipiano. É verdade que no escrito sobre "O mal-estar na civilização" Freud reitere o sentimento de culpa à "consequência dos atos de agressão de que alguém se abstivera: em outro, porém - exatamente em seu começo histórico, a morte do pai -, constituía a consequência dos atos de agressão que fora executado" (1996/1930, pág. 140), porém, pela pulsão de morte, podemos tomar a letra freudiana para subvertê-la, descrevendo o mortífero da pulsão como anterioridade a toda causa edipiana.

Portanto, é mesmo da retomada lacaniana da obra de Freud que se trata. Afinal, como afirmado por Safatle (2007), a pulsão de morte é descrita por Freud como um conceito que emperra a análise e a rememoração, sendo tomada como um limite à análise e à simbolização - "A pulsão de morte não será incorporada pela clínica freudiana como motor dos processos de cura" (pág. 166). É a partir de Lacan, que Safatle menciona a possibilidade de retomar a pulsão de morte, dando à essa um novo estatuto. Veremos assim uma modificação da própria psicopatologia psicanalítica, e, por consequência, do tratamento analítico.

Certamente repensar a psicopatologia nos conduz à evocar o complexo de Édipo pela perspectiva do Nome-do-Pai em Jacques Lacan. Não ignorando a importância desse conceito (na medida em que é reformulada pela pulsão de morte), deixaremos para abordá-lo numa próxima oportunidade. Por ora, nos contentaremos em explicitar o modo como a pulsão de morte modifica a prática psicanalítica, permitindo distanciá-la da psicopatologia psiquiátrica, segundo as exigências de cura e moralização do sexual. 
Pela centralidade da pulsão de morte, o tratamento psicanalítico não visa limitar o impulso de destruição da pulsão de morte pela ligação propiciada por Eros (pulsão sexual reformulada pela pulsão de vida). Pelo contrário, trata-se de produzir uma ruptura da unidade propiciada pelo Eros, unidade que é essencialmente narcísica e imaginária. Ao produzir uma ruptura da unidade narcísica com o Eros, veremos uma cisão, de certo modo, dos ideais normativos e do grande Outro - na medida em que esse último configura a onipotência ilusória de que haveria o fechamento das feridas narcísicas pelo saber de Eros. Evidentemente, o Outro está incluído na construção singular do sujeito, mas esse Outro não carrega as marcas determinantes de um saber sobre o sujeito. Pode-se dizer que o sujeito é atravessado pelo Outro e seu saber, mas esse não esgota a relação de causa- efeito para o sujeito.

Portanto, a prática psicanalítica apresenta a noção de sujeito como um termo que se mantém como furo ao Outro do saber jurídico-médico. Ela assim sustenta o impasse diagnóstico vivido pela psiquiatria e pelo sistema penitenciário no início dos séculos XVIII e XIX. Deste modo, nos permite pensar o "a-normal" não como resposta à demanda médico-jurídica, mas essencialmente como aquele que se inscreve como impossibilidade radical ao saber da psiquiatria e do sistema judiciário. Isso permite que a psicanálise, pela noção de sujeito (a-normal), se distancie do discurso moral na medida em que o último é responsável pela regularização do sexual. Afinal, a pulsão de morte, como a causa maior, é por excelência incapaz de ser normatizada ou domesticada por objetos mais aprazíveis à consciência moral.

\section{Referência:}

Dunker, C. (2011). Estrutura e constituição da clínica psicanalítica: Uma arqueologia das práticas de cura, psicoterapia e tratamento. Annablume.

Dunker, C. \& Kyrillos-Neto, F. (2015). Psicanálise e saúde mental. Doces Bárbaros.

Foucault, M. (2010/1975). Os anormais. Martins Fontes.

Foucault, M. (2013/1973). A verdade e as formas jurídicas. Ed. Nau. 
Freud, S. (1996/1905). Três ensaios da teoria da sexualidade. In Freud, S., Edição standard brasileira das obras psicológicas completas de Sigmund Freud (v. VII, págs. 119-229). Imago.

Freud, S. (1996/1912). Contribuições a um debate sobre a masturbação. In Freud, S., Edição standard brasileira das obras psicológicas completas de Sigmund Freud (vol. XII, págs. 259-274). Imago.

Freud, S. (1996/1916). Alguns tipos de caráter encontrados no trabalho psicanalítico. In Freud, S., Edição standard brasileira das obras psicológicas completas de Sigmund Freud (vol. XIV, págs. 325-350). Imago.

Freud, S. (1996/1930). O mal-estar na civilização. In Freud, S., Edição standard brasileira das obras psicológicas completas de Sigmund Freud (vol. XXI, págs. 67-150). Imago.

Freud, S. (2006/1920). Além do Princípio de Prazer. In Hanns, L. A. (Coord.), Escritos sobre a psicologia do inconsciente: Obras Psicológicas de Sigmund Freud (vol. II, págs. 123-197). Imago.

Freud, S. (2011/1924). A dissolução do complexo de Édipo. In Freud, S., Obras completas (vol.16, págs. 203-213). Companhia das Letras.

Freud, S. (2017/1890). Tratamento psíquico. In Freud, S., Obras incompletas de Sigmund Freud (vol. VI, págs. 19-46). Autêntica.

Haute, V. \& Geyskens, T. (2017). Psicanálise sem Édipo? Uma antropologia clínica da histeria em Freud e Lacan. Autêntica Editora.

Jardim, E. (2013). Prefácio à quarta edição. In Foucault, M., A verdade e as formas jurídicas. Ed. Nau.

Lacan, J. (1998/1955). O seminário sobre 'A carta roubada'. In Escritos (V. Ribeiro, trad., págs. 13-68). Jorge Zahar.

Moraes, E. (2013). Inventário do abismo: In Sade, M., Os 120 dias de Sodoma. Iluminiuras.

Poe, Edgar. (1999). A carta roubada. Imago.

Rosa, M. (2018). O perigo da infância: uma armadilha para pegar adultos. Psicologia em Revista, 24(1), 318-329.

Quinet, A. (2015). Édipo ao pé da letra: fragmentos de tragédia e psicanálise. Zahar.

Sade, M. (2013). Os 120 dias de Sodoma ou a escola da libertinagem. Iluminuras.

Safatle, V. (2007). A teoria das pulsões como ontologia negativa. Revista Dossiê Filosofia e Psicanálise, (36), 148-189.

Sófocles. (1958). Sófocles: o Rei Édipo. (Cláudio Brandão, trad.). Kriterion. 